\title{
$\nabla$
}

\section{Assessment of the quality of life of pediatric patients with the major chronic childhood skin diseases ${ }^{*}$}

\author{
Avaliação da qualidade de vida em pacientes pediátricos com as principais \\ dermatoses crônicas da infância
}

\author{
Ana Paula Dornelles da Silva Manzoni ${ }^{1}$ \\ Roberta Zaffari Townsend ${ }^{2}$ \\ Aline Rodrigues da Silva Nagatomi ${ }^{2}$
}

\author{
Rita Langie Pereira ${ }^{2}$ \\ Magda Blessmann Weber ${ }^{3}$ \\ Tania Ferreira Cestari ${ }^{4}$
}

\begin{abstract}
BACKGROUND: The skin is the primary interface of the human being with the external environment and the presence of skin diseases can have substantial effects on the quality of life.

OBJECTIVE: This study aims to make a comparative evaluation of the quality of life of pediatric patients with atopic dermatitis, psoriasis and vitiligo and correlate the findings with the total body surface and the areas with the disease exposed to view. MEтHODS: The sample consisted of 118 patients with atopic dermatitis, vitiligo and psoriasis, aged between 5 and 16 years, who were asked to answer the Children's Dermatology Life Quality Index (CDLQI) questionnaire. A dermatological examination for the measurement of total body surface affected by the disease was performed.

REsults: The three groups showed an impaired quality of life. Patients with atopic dermatitis and psoriasis showed a significantly greater impact on the QoL than the group with vitiligo. There is a trend towards impaired quality of life in patients from the three groups of dermatoses, which is related to increments in both the total affected area and affected area exposed to view ( $\mathrm{r}=0.428$ and $\mathrm{p}<0.001, \mathrm{r}=0.381$ and $\mathrm{p}<0.001$, respectively).

Conclusion: The assessed children had impaired quality of life. However, there is a significantly greater impact in the groups with atopic dermatitis and psoriasis than in the group with vitiligo. This may be due to lack of symptoms in vitiligo and the fact this group presented a statistically smaller affected body surface than the other two groups.
\end{abstract}

Keywords: Child; Dermatitis, atopic; Psoriasis; Quality of life; Vitiligo

Resumo: Fundamentos: A pele é a principal interface do ser humano com o meio externo e a presença de doenças cutâneas pode levar a repercussões importantes na qualidade de vida.

OвJETIVOS: O presente estudo tem como objetivo fazer uma avaliação comparativa entre a qualidade de vida dos pacientes pediátricos com dermatite atópica, vitiligo e psoríase e correlacioná-la à superfície corporal total e às áreas expostas à visualização acometidas pela doença.

MÉTODOs: Amostra composta por 118 pacientes com dermatite atópica, vitiligo e psoríase na faixa etária entre 5 a 16 anos para a aplicação do questionário Índice de Qualidade de Vida para Dermatologia em Crianças (CDLQI). Realizado exame dermatológico para a aferição da superfície corporal total acometida pela doença.

RESULTADOS: Os três grupos de pacientes pediátricos demonstraram ter redução na qualidade de vida. Os pacientes com dermatite atópica e psoríase apresentaram um impacto na QoL significativamente maior que o grupo com vitiligo. Há uma tendência na redução da qualidade de vida dos pacientes dos três grupos de dermatoses relacionado ao aumento tanto da superfície total quanto da superfície exposta à visualização ( $r=0,428$ e $p<0,001 ; r=0,381$ e $p<0,001$, respectivamente).

ConClusão: As crianças avaliadas com dermatite atópica, psoríase e vitiligo apresentaram redução na qualidade de vida. Porém, há um impacto significativamente maior nos grupos de pacientes com dermatite atópica e psoríase em relação ao grupo com vitiligo. Este fato pode dever-se a ausência de sintomas no vitiligo e ao grupo ter apresentado uma superfície corporal comprometida estatisticamente menor que outros dois grupos.

Palavras-chave: Criança; Dermatite atópica; Psoríase; Qualidade de vida; Vitiligo

Received on 06.03.2011

Approved by the Advisory Board and accepted for publication on 28.06.2011.

* Work performed at the Dermatology Service of the Hospital de Clínicas de Porto Alegre of the Universidade Federal do Rio Grande do Sul (HCPA-UFRGS) Dermatology Service of the Universidade Federal de Ciências da Saúde de Porto Alegre (UFCSPA) - Discipline of Dermatology - of the Universidade Luterana do Brasil (ULBRA) - Porto Alegre (RS), Brazil

Conflict of interest: None / Conflito de interesse: Nenbum

Financial Support: Fundação Instituto de Pesquisas Econômicas (FIPE).

\footnotetext{
PhD - Colaborating Professor at the Universidade Federal de Ciências da Saúde de Porto Alegre (UFCSPA) - Porto Alegre (RS), Brazil

Physician in Private Clinic - Porto Alegre (RS), Brazil.

PhD - Assistant Professor of the Universidade Federal de Ciências da Saúde de Porto Alegre(UFCSPA) - Porto Alegre (RS), Brazil.

$\mathrm{PhD}$ - Associate Professor of the Universidade Federal do Rio Grande do Sul (UFRGS) - Porto Alegre (RS), Brazil. 


\section{INTRODUCTION}

Nowadays there is an increased interest in issues that contemplate the impact of dermatological disease on psychological, social and economic aspects. ${ }^{1-3}$ As the skin is the main interface of the human being with the external environment, the presence of cutaneous abnormalities can lead to important repercussions on the quality of life (QoL) of these patients. ${ }^{1,4,5}$ It is believed that this is due to the important function of the skin on the development of the body image and on the constitution of the ego. As a consequence, the patients with dermatoses are more susceptible to psychological diseases and negative social repercussions.

Atopic dermatitis (AD), vitiligo (Vi) and psoriasis (Ps) are important chronic childhood dermatoses and the literature has been demonstrating their impact on the QoL of the affected children. ${ }^{1,78}$ Atopic dermatitis is considered the most common of them (10-20\%) and its prevalence is increasing. ' Some authors estate that its typical clinical manifestations, the itch and the eczema, together with the overload resulting from the permanent preventive routine and therapy lead to psycho-social repercussions. ${ }^{10}$ Vitiligo affects around $1 \%$ of the general population and, in general, $50 \%$ of those are younger than 20 years. ${ }^{11,12}$ Its is characterized by a dyspigmentation of the skin and, despite being a asymptomatic dermatosis, it is significantly linked to impairment of the quality of life..$^{11,12,13}$ Psoriasis is an erythematous-desquamative disease and the prevalence is up to $3 \%$ in the general population and $4 \%$ before the age of 16 years. ${ }^{14}$ Despite being the pediatric dermatosis with the smallest frequency of the three studied, the literature strongly demonstrates the presence of stress, low self-esteem, social discrimination and psychiatric abnormalities. ${ }^{15,16}$

In order to dimension the impact on the quality of life of the pediatric population with dermatoses, instruments capable of quantifying the subjective aspects of the disease and that allow a more complete vision of the patients were created. ${ }^{17,18}$ The score of the Children's Dermatology Life Quality Index - CDLQI is an established instrument which allowed the assessment of pediatric age patients and has been widely tested and validated for the Brazilian Portuguese language., ${ }^{1,19}$

In order to assist with the understanding of the psycho-social repercussions secondary to the main pediatric chronic dermatoses, the present study aims at making a comparative assessment of the quality of life of patients with atopic dermatitis, vitiligo and psoriasis and associating it with the total body surface and the areas affected by the disease exposed to visualization. In conjunction with that, a critical and comparative analysis with the world data which highlights the importance of the subject will be performed.

\section{MATERIAL AND METHODS}

\section{Sample}

The study was performed with 118 pediatric patients with atopic dermatitis (AD), vitiligo (Vi) and psoriasis (Os) diagnosed according to the classic clinical criteria for these dermatoses. ${ }^{7,8,14}$ In case of doubt, a histopathological exam was used for confirmation. The age range of the patients went from 5 to 16 years, appropriate for the use of the Children's Dermatology Life Quality Index. The sample was calculated with a significance level of $5 \%$ and Power of $80 \%$ for comparison among the CDLQI averages. The data collection was conducted at the Dermatology outpatients clinic of the Centro de Saúde Santa Marta of the Universidade Federal de Ciências da Saúde de Porto Alegre, at the Dermatology outpatients clinic of the Hospital de Clínicas of the Universidade Federal do Rio Grande do Sul and at the Dermatology outpatients clinic of the Centro de Saúde IAPI of the Universidade Luterana do Brasil, between December 2008 and July 2010.

The following items were considered as exclusion criteria: disease diagnosed less than six months before, presence of other chronic illnesses under treatment and use of neuro-psychiatric medication.

\section{Instruments for data collection and variables analyzed}

The following variables were collected: patient's age, sex and duration of the disease. A complete dermatological examination was conducted for the mapping of the total body surface affected and the areas exposed to visualization. The calculation of the percentage of the body surface was performed according to the human model for burns. ${ }^{20}$

Quality of Life (QoL): the patients answered the CDLQI questionnaire developed by Lewis-Jones and Finlay and validated for the Brazilian Portuguese by Prati et al. ${ }^{19,21}$ This instrument is composed of 10 questions and contemplates 6 domains - symptoms and feelings, leisure, school/vacation, personal relations, sleep and treatment. The patient must choose one of the four available answers for each question: 3 "very much", 2 "a lot", 1 "a little" e 0 "no". When adding up the scores, 0 to 1 are considered as having no impact on the quality of life, from 2 to 6 a small impact, from 7 to 12 a moderate impact, from 13 to 18 a large impact and from 19 to 30 an extreme impact. The CDLQI scale is validated for the Brazilian Portuguese language. ${ }^{19}$

\section{Statistical Analysis}

The qualitative variables were described as the absolute frequency and the relative frequency. The quantitative variables were described as average and 
standard deviation when they had a normal distribution or otherwise as median and interquartile interval. The association between the qualitative variables and the groups of dermatoses was done by the chi-square test. The average of the quantitative variables in relation to the groups was done with the Variance Analysis and, whenever it was significant, the Tukey's Multiple Comparisons Test was used as a complement. The quantitative variables that did not fulfill the assumption of normality and the ordinal qualitative variables were compared using the Kruskal-Wallis test when different groups were compared. In order to control the effects of the body surface, the underlying disease and the duration of the disease on the quality of life, logistic regression was used.

\section{Ethical Considerations}

The data was collected after approval by the Research Ethics Committee and the formal consent by the guardians. The patients were invited to participate and their will was respected without compromise of the clinical follow-up.

\section{RESULTS}

118 patients were assessed, 55\% of them female; patients with atopic dermatitis predominated $(42,3 \%)$ followed by those with vitiligo $(36,4 \%)$ and psoriasis $(21,3 \%)$. There was a significantly smaller sample of the group with psoriasis due to the lower prevalence of this disease on the age range studied.

The comparative analyses of the quality of life on the three groups of dermatoses showed that the patients with atopic dermatitis and psoriasis had an impact on the QoL significantly higher that the group with vitiligo (Table 1). When this impact is evaluated according to the total body surface and the body surface area affected by the disease exposed to visualization, a tendency to worsening of the QoL from patients from the three groups of dermatoses was observed, both in relation to the increasing of the total body surface $(r=0,428$ and $p<0,001)$ and the exposed surface $(r=0,381$ and $p<0,001)$ affected by the disease (Table1). It is worth highlighting that the total body surface and that exposed to visualization were significantly higher in the groups with atopic dermatitis and psoriasis than in the group with vitiligo.

When performed a dichotomization in order to compare the absence (scores 0 or 1 on the CDLQI) or the presence (scores 2 or more on the CDLQI) of any impact on the quality of life it was noted that the group with atopic dermatitis is statistically associated with an impairment on the patients' QoL and the group with vitiligo is associated with the absence of a impact on the QoL $\left(c^{2}=15,77 ; p<0,001\right)$. When assessing the moderate to severe impact on the quali- ty of life of the three groups of dermatoses (scores 6 or more on the CDLQI), it was observed by logistic regression analysis that the patients with atopic dermatitis had 4,65 times more chance of having impaired quality of life when compared with the patients with vitiligo. The patients with psoriasis had 2,7 times more chance of having impaired quality of life when compared with those from the vitiligo group.

The analysis of the questions that compose the CDLQI showed that the patients with atopic dermatitis and psoriasis had a statistically higher impact than the group with vitiligo on the following questions: presence of symptoms, change on dressing habits and presence of sleep disturbances secondary to the disease (Table 2).

When the analysis of the CDLQI through its domains was performed, it was noted that on the domains "symptoms and feelings" and "leisure" the groups with atopic dermatitis and psoriasis had significantly higher scores that the group with vitiligo. On the domain "personal relations", the patients with psoriasis had significantly higher scores than the patients with vitiligo. On the "sleep" domain, the atopic patients had significantly worse scores than the patients with vitiligo. The domains "school/vacation" and "treatment" did not present statistical differences among the groups (Table 3).

The evaluation of the CDLQI domains in relation to the total exposed area and exposed area affected by the disease, a significant correlation between the presence of a larger total body surface and affected exposed area and worse scores on the domains, "symptoms and feelings" $(\mathrm{p}<0,01)$, "personal relations" $(p<0,01)$ and "leisure" $(p<0,01)$ was observed. The domains "sleep" and "treatment" only had significance when related to a larger total body surface affected by the disease $(p=0,012$ and $p=0,04$, respectively). The domain "school/vacation" did not show significant correlations with the affected body area.

\section{DISCUSSION}

Children with atopic dermatitis, psoriasis and vitiligo assessed on the present study showed an impairment of their quality of life. This finding is well described on the literature however, when the three groups are compared, peculiarities still not reported on the pediatric population are observed. ${ }^{6,18,22,23,24}$

The groups with atopic dermatitis and psoriasis had a statistically significant impairment of their quality of life in relation to the group of patients with vitiligo. Publications which performed a similar analysis comparing only patients with atopic dermatitis and psoriasis also observed an impairment on the QoL in both groups, with no statistically significant difference 
Table 1: Comparative analysis between the groups and quality of life, total body surface affected by the disease and areas exposed to visualization

\begin{tabular}{|c|c|c|c|c|c|c|}
\hline & \multicolumn{6}{|l|}{ Group } \\
\hline & \multicolumn{2}{|c|}{$\begin{array}{l}\text { Atopic } \\
\text { Dermatitis }\end{array}$} & \multicolumn{2}{|l|}{ Vitiligo } & \multicolumn{2}{|l|}{ Psoriasis } \\
\hline & $\begin{array}{l}\text { Median } \\
(\text { P25-P75) }\end{array}$ & $\begin{array}{l}\text { Average } \\
\text { ranking }\end{array}$ & $\begin{array}{l}\text { Median } \\
(\text { P25-P75) }\end{array}$ & $\begin{array}{l}\text { Average } \\
\text { ranking }\end{array}$ & $\begin{array}{l}\text { Median } \\
(\text { P25-P75) }\end{array}$ & $\begin{array}{l}\text { Average } \\
\text { ranking }\end{array}$ \\
\hline $\begin{array}{l}\text { Scores of Quality of Life } \\
\text { by the CDLQI }\end{array}$ & $\begin{array}{l}9 \\
(5-13)\end{array}$ & $72,7^{A}$ & $\begin{array}{l}2 \\
(1-6)\end{array}$ & $39,66^{\text {в }}$ & $\begin{array}{l}7 \\
(3-14,5)\end{array}$ & $67,2^{A}$ \\
\hline Total body surface (\%) & $\begin{array}{l}9,5 \\
(6-24,3)\end{array}$ & $71,7^{\mathrm{A}}$ & $\begin{array}{l}4 \\
(2-8)\end{array}$ & $44,3^{\text {в }}$ & $\begin{array}{l}6 \\
(2-37)\end{array}$ & $61,3^{A}$ \\
\hline Exposed body surface (\%) & $\begin{array}{l}3 \\
(0,8-6,3)\end{array}$ & $67,71^{A}$ & $\begin{array}{l}0 \\
(0-2)\end{array}$ & $41,81^{\text {в }}$ & $\begin{array}{l}4 \\
(1-6,5)\end{array}$ & $73,50^{\mathrm{A}}$ \\
\hline
\end{tabular}

Average rankings followed by distinct letters differ significantly by the Non-parametrical Kruskal Wallis test, complemented by its Multiple Comparisons Test, at the significance level of $5 \%$.

between them. ${ }^{9,22,23,24}$ Another study which analyses the presence of negative emotions in adult patients with psoriasis, vitiligo and a control group showed that the patients with Ps suffered more emotional repercussions than the patients with vitiligo and the control ones. ${ }^{6}$ Our study also demonstrated that pediatric patients with atopic dermatitis and psoriasis had a worse QoL than patients with vitiligo ad we believe that this is due to the fact that the vitiligo is an asymptomatic dermatosis and it is less associated with periods of exacerbation and hospitalization than the psoriasis and atopic dermatitis. ${ }^{6,9,22,23,24}$

When a comparative analyzes among the groups with moderate to severe impact on their quality of life was performed, the patients with atopic dermatitis had 4,65 times more chances of having impaired quality of life and the patients with psoriasis had 2,7 times higher risk when compared with the patients with vitiligo. This tendency is also seem in other scientific publications which compare $\mathrm{AD}$ and diseases considered as being more serious like cystic fibrosis, diabetes and chronic renal diseases. ${ }^{6,9,21,22,23,24,25}$

In the analysis of the impact on the patients' quality of life according to total body surface and to the areas affected by the disease exposed to visualization, a tendency to an impaired QoL was observed on patients from the three groups of dermatoses. When analyzed by CDLQI domains, a significant correlation between the presence of a larger total body surface and affected exposed area and worse scores on the domains "symptoms and feelings", "personal rela- tions" and "leisure" was observed. The domains "sleep" and "treatment" only had significance when associated with a larger total body surface affected by the disease. The literature explains these findings by the presence of feelings like shame, limitation under leisure situations that require body exposure and a longer time needed to carry out more complex treatments. ${ }^{3,4,26,27}$ In terms of the significance between the worsening of the quality of life and the presence of lesions in visible areas, the authors propose the existence of the stigma against the visibility of the cutaneous lesions which is capable of influencing the development of psychic illnesses and impairment of the patients' quality of life. ${ }^{4,10,12}$ Some authors describe a phenomenon which associates the visibility of the dermatoses with a worse perception of the disease, regardless of the presence of symptoms and the total body surface affected. ${ }^{28}$

The analysis of the questions that comprise the CDLQI demonstrated that the patients with atopic dermatitis and psoriasis had statistically higher scores than the group with vitiligo on the questions related to the presence of symptoms of the disease, the changes of the type of clothing in order to cover the lesions and the presence of sleep disturbances. Some publications have already described this impact and they suggest that it is due to numerous factors associated with negative feelings like dissatisfaction with their appearance, anxiety, depression, shame, sadness, lower self-esteem, stigmatization, social life restriction and worse quality of sleep. , $16,17,26,27,29^{2}$ 
Table 2: Comparative analysis between the three groups of dermatoses and the questions which assess the quality of life by the CDLQI

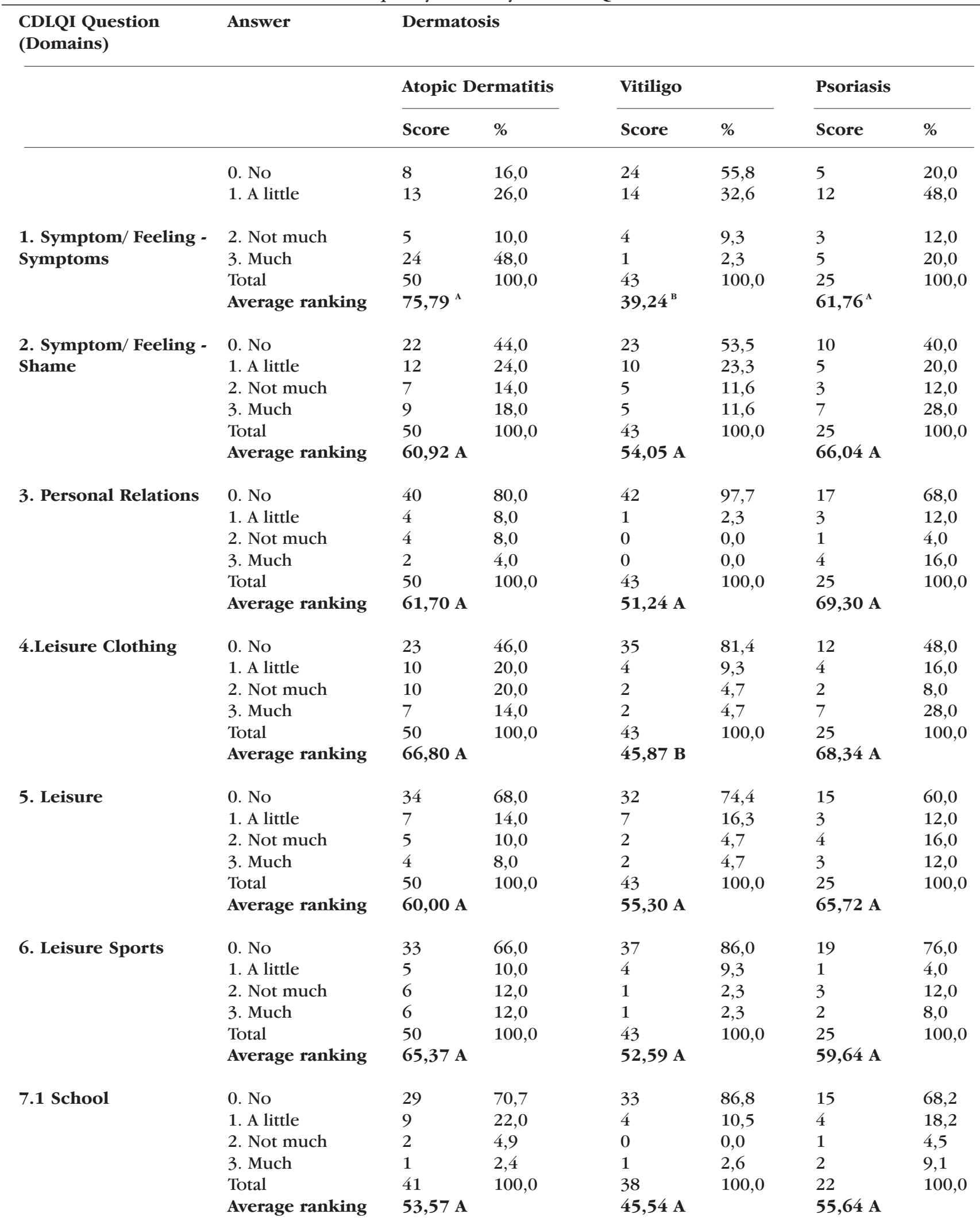




\begin{tabular}{|c|c|c|c|c|c|c|c|}
\hline \multirow{3}{*}{$\begin{array}{l}\text { CDLQI Question } \\
\text { (Domains) }\end{array}$} & \multirow[t]{3}{*}{ Answer } & \multicolumn{6}{|c|}{ Dermatosis } \\
\hline & & \multicolumn{2}{|c|}{ Atopic Dermatitis } & \multicolumn{2}{|l|}{ Vitiligo } & \multicolumn{2}{|c|}{ Psoriasis } \\
\hline & & Score & $\%$ & Score & $\%$ & Score & $\%$ \\
\hline \multirow[t]{6}{*}{7.2 Vacation } & 0. No & 9 & 90,0 & 7 & 77,8 & 3 & 60,0 \\
\hline & 1. A little & 0 & 0,0 & 1 & 11,1 & 1 & 20,0 \\
\hline & 2. Not much & 1 & 10,0 & 1 & 11,1 & 0 & 0,0 \\
\hline & 3. Much & 0 & 0,0 & 0 & 0,0 & 1 & 20,0 \\
\hline & Total & 10 & 100,0 & 9 & 100,0 & 5 & 100,0 \\
\hline & Average ranking & \multicolumn{2}{|l|}{$11,25^{\mathrm{A}}$} & \multicolumn{2}{|l|}{$12,56^{\mathrm{A}}$} & \multicolumn{2}{|l|}{$14,90^{\mathrm{A}}$} \\
\hline 8. Personal Relations - & 0. No & 33 & 66,0 & 31 & 72,1 & 13 & 54,2 \\
\hline \multirow[t]{5}{*}{ Bullying } & 1. A little & 3 & 6,0 & 5 & 11,6 & 5 & 20,8 \\
\hline & 2. Not much & 8 & 16,0 & 6 & 14,0 & 1 & 4,2 \\
\hline & 3. Much & 6 & 12,0 & 1 & 2,3 & 5 & 20,8 \\
\hline & Total & 50 & 100,0 & 43 & 100,0 & 24 & 100,0 \\
\hline & Average ranking & \multicolumn{2}{|l|}{$59,84 \mathrm{~A}$} & \multicolumn{2}{|l|}{$54,15 \mathrm{~A}$} & \multicolumn{2}{|c|}{$65,94 \mathrm{~A}$} \\
\hline \multirow{6}{*}{ 9. Sleep } & 0. No & 23 & 46,0 & 39 & 90,7 & 15 & 60,0 \\
\hline & 1. A little & 5 & 10,0 & 3 & 7,0 & 5 & 20,0 \\
\hline & 2. Not much & 7 & 14,0 & 0 & 0,0 & 2 & 8,0 \\
\hline & 3. Much & 15 & 30,0 & 1 & 2,3 & 3 & 12,0 \\
\hline & Total & 50 & 100,0 & 43 & 100,0 & 25 & 100,0 \\
\hline & Average ranking & \multicolumn{2}{|l|}{$72,34 \mathrm{~A}$} & \multicolumn{2}{|l|}{$43,77 \mathbf{B}$} & \multicolumn{2}{|l|}{$60,88 \mathrm{~A}$} \\
\hline \multirow[t]{6}{*}{ 10. Treatment } & 0. No & 21 & 42,0 & 24 & 55,8 & 14 & 56,0 \\
\hline & 1. A little & 12 & 24,0 & 13 & 30,2 & 5 & 20,0 \\
\hline & 2. Not much & 10 & 20,0 & 3 & 7,0 & 2 & 8,0 \\
\hline & 3. Much & 7 & 14,0 & 3 & 7,0 & 4 & 16,0 \\
\hline & Total & 50 & 100,0 & 43 & 100,0 & 25 & 100,0 \\
\hline & Average ranking & $65,49 \mathrm{~A}$ & 53,81 A & \multicolumn{2}{|l|}{ 57,30 A } & & \\
\hline
\end{tabular}

Average rankings followed by distinct letters differ significantly by the Non-parametrical Kruskal Wallis test, complemented by its Multiple Comparisons Test, at the significance level of $5 \%$.

Table 3: Comparative analysis between the three groups of dermatoses and the domains that assess the quality of life by the CDLQI

\begin{tabular}{|c|c|c|c|c|c|c|}
\hline & \multicolumn{6}{|l|}{ Group } \\
\hline & \multicolumn{2}{|c|}{ Atopic Dermatitis } & \multicolumn{2}{|l|}{ Vitiligo } & \multicolumn{2}{|l|}{ Psoriasis } \\
\hline & $\begin{array}{l}\text { Median } \\
\text { (P25-P75) }\end{array}$ & $\begin{array}{l}\text { Average } \\
\text { ranking }\end{array}$ & $\begin{array}{l}\text { Median } \\
\text { (P25-P75) }\end{array}$ & $\begin{array}{l}\text { Average } \\
\text { ranking }\end{array}$ & $\begin{array}{l}\text { Median } \\
\text { (P25-P75) }\end{array}$ & $\begin{array}{l}\text { Average } \\
\text { ranking }\end{array}$ \\
\hline Symptoms and Feelings & $3(1-4)$ & $71,94^{\mathrm{A}}$ & $1(0-2)$ & $42,02 \mathrm{~B}$ & $3(1-4)$ & $64,68^{A}$ \\
\hline Personal Relations & $0(0-2)$ & $61,74^{\mathrm{AB}}$ & $0(0-1)$ & $50,91 \mathrm{~B}$ & $1(0-3)$ & $69,80^{A}$ \\
\hline Leisure & $1,5(0-4)$ & $66,32^{A}$ & $0(0-1)$ & $47,97 \mathrm{~B}$ & $1(0-4,5)$ & $65,70^{A}$ \\
\hline School/Vacation & $0(0-1)$ & $60,52^{A}$ & $0(0-0)$ & $54,92 \mathrm{~A}$ & $0(0-1)$ & $65,34^{\mathrm{A}}$ \\
\hline Sleep & $1(0-3)$ & $72,34^{\mathrm{A}}$ & $0(0-0)$ & $43,77 \mathrm{~B}$ & $0(0-1)$ & $60,88^{\mathrm{AB}}$ \\
\hline Treatment & $1(0-2)$ & $65,49^{A}$ & $0(0-1)$ & $53,81 \mathrm{~A}$ & $0(0-1,5)$ & $57,30^{\mathrm{A}}$ \\
\hline
\end{tabular}

Average rankings followed by distinct letters differ significantly by the Non-parametrical Kruskal Wallis test, complemented by its Multiple Comparisons Test, at the significance level of 5\%. 
However, some authors also reported a significant impairment on the QoL of patients with vitiligo, but none of them assessed the three groups of dermatoses comparatively.

It is necessary to observe that the total body surface and the surface exposed to the visualization are significantly larger on the groups with atopic dermatitis and psoriasis in relation to the group with vitiligo, and this fact might influence the quality of life of the groups. Another relevant fact is that atopic dermatitis and psoriasis are diseases related to the presence of symptoms like itch, burning sensation and pain, whereas the vitiligo is characteristically asymptomatic. ${ }^{3,12,14,18,24}$

One of the limitations to a deeper analysis of the present study is the reduced number of patients with psoriasis due to its lower prevalence on the age range studied.

The results from this study allow us to conclude that pediatric patients with atopic dermatitis, psoriasis and vitiligo have an impaired quality of life. Comparatively, the groups with atopic dermatitis and psoriasis demonstrated a significantly higher impact than the group with vitiligo. Furthermore, the bigger compromise of the total body surface and of the visible areas with the disease influenced the impairment of the quality of life of the patients from the three groups of dermatoses.

\section{CONCLUSION}

The children with atopic dermatitis, psoriasis and vitiligo assessed in this study had an impairment of their quality of life. However, there is significantly higher impact on the group of patients with atopic dermatitis and psoriasis in relation to the group with vitiligo. This might be due to the absence of symptoms in vitiligo and to the fact that this group had a statistically smaller body surface affected by the disease than the other two groups. 


\section{REFERENCES}

1. Weber MB, Fontes Neto Pde T, Prati C, Soirefman M, Mazzotti NG, Barzenski B, et al. Improvement of pruritus and quality of life of children with atopic dermatitis and their families after joining support groups. J Eur Acad Dermatol Venereol. 2008;22:992-7.

2. Hong J, Koo B, Koo J. The psychosocial and occupational impact of chronic skin disease. Dermatol Ther. 2008;21:54-9.

3. Kotrulja L, Tadinac M, Joki-Begi NA, Gregurek R. A multivariate analysis of clinical severity, psychological distress and psychopathological traits in psoriatic patients. Acta Derm Venereol. 2010;90:251-6.

4. Ludwig MWB, Muller MC, Oliveira MS, Moraes JFD. Qualidade de vida e localização das lesões em pacientes dermatológicos. An Bras Dermatol. 2009;84:143-50.

5. Manzoni APDS, Grazziotin TC. Psicodermatoses na infância. In: Weber MB, Fontes Neto PT. Psicodermatologia. São Caetano do Sul, SP. São Paulo: Yendis; 2009.

6. Kossakowska MM, Cieciska C, Jaszewska J, Placek WJ. Control of negative emotions and its implication for illness perception among psoriasis and vitiligo patients. J Eur Acad Dermatol Venereol. 2010;24:429-33.

7. Benoit S, Hamm H. Childhood psoriasis. Clin Dermatol. 2007;25:555-62.

8. Huggins RH, Schwartz RA, Janniger CK. Childhood vitiligo. Cutis. 2007;79:277-80.

9. Beattie PE, Lewis-Jones MS. A comparative study of impairment of quality of life in children with skin disease and children with other chronic childhood diseases. $\mathrm{Br} J$ Dermatol. 2006;155:145-51.

10. Carroll CL, Balkrishnan R, Feldman SR, Fleischer AB, Manuel JC. The Burden of Atopic Dermatitis: Impact on the Patient, Family, and Society. Pediatr Dermatol. 2005;22:192-9

11. Sampogna F, Raskovic D, Guerra L, Pedicelli C, Tabolli S, Leoni L, et al. Identification of categories at risk for high quality of life impairment in patients with vitiligo. $\mathrm{Br} J$ Dermatol. 2008;159:351-9.

12. Linthorst Homan MW, de Korte J, Grootenhuis MA, Bos JD, Sprangers MA, van der Veen JP. Impact of childhood vitiligo on adult life. Br J Dermatol. 2008;159:915-20.

13. Parsad D, Dogra S, Kanwar AJ. Quality of life in patients with vitiligo. Health Qual Life Outcomes. 2003;1:58.

14. Paller AS, Mancini AJ. Lesões pápulo-escamosas e doenças relacionadas. In: Palle AS, Mancini AJ, editores. Hurwitz - Dermatologia Pediátrica - Tratado de doenças de pele na infância e na adolescência. Rio de Janeiro: Revinter; 2009. p. 85-105.

15. Fortune DG, Richards HL, Kirby B, Bowcock S, Main CJ, Griffiths CEM. A cognitivebehavioral symptom management programme as an adjunct un psoriasis therapy. $\mathrm{Br}$ J Dermatol. 2002;146:458-65.

16. Hayes J, Koo J. Psoriasis: depression, anxiety, smoking, and drinking habits Dermatol Ther. 2010;23:174-80.

17. Basra MKA; Fenechf, Gatt RM, Salek MS, Finlay AY. The Dermatology Life Quality Index 1994-2007: A Comprehensive Review of Validation Data and Clinical Results. Br J of Dermatol. 2008;159:997-1035.

18. Beattie PE, Lewis-Jones MS. A comparative study of impairment of quality of life in children with skin disease and children with other chronic childhood diseases. Br J Dermatol. 2006;155:145-51.
19. Prati C, Comparin C, Boza JC, Cestari TF. Validação para o português falado no Brasil do instrumento Escore da Qualidade de Vida na Dermatologia Infantil (CDLQI). Med Cutan Iber Lat Am. 2010;38:229-33.

20. Vale ECS. Primeiro Atendimento em queimaduras: a abordagem do dermatologista. An Bras Dermatol. 2005;80:9-19.

21. Lewis-Jones S, Finlay AY. The Childrens Dermatology Life Quality Index (CDLQI): initial validation and practical use. Br J Dermatol. 1995;132:942-9.

22. Grob J, Revuz J, Ortonne JP, Auquier P, Lorette G. Comparative study of the impact of chronic urticaria, psoriasis and atopic dermatitis on the quality of life. $\mathrm{Br} \mathrm{J}$ Dermatol. 2005;152:289-95.

23. Lundberg L, Johannesson M, Silverdahl M, Hermansson C, Lindberg M. Quality of life, health-state utilities and willingness to pay in patients with psoriasis and atopic eczema. Br J Dermatol. 1999:141:1067-75.

24. Lundberg L, Johannesson M, Silverdahl M, Hermansson L, Lindberg M. Health-related quality of life in patients with psoriasis and atopic dermatitis measured with SF36, DLQI and a subjective measure of disease activity. Acta Derm Venereol. 2000;80:430-4.

25. Su JC, Kemp AS, Varigos GA. Atopic eczema: its impacto on the family and financial cost. Arch Dis Child. 1997;76:159-62.

26. Eghlileb AM, Davies EEG, Finlay AY. Psoriasis has a major secondary impact on lives of family members and partners. Br J Dermatol. 2007;156:1245-50.

27. Potocka A, Turczyn-Jabloñska K, Merecz D. Psychological correlates of quality of life indermatology patients: the role of mental health and self-acceptance. Acta Dermatovenerol Alp Panonica Adriat. 2009;18:53-8, 60, 62.

28. Firooz A, Bouzari N, Fallah N, Ghazisaidi B, Firoozabadi MR, Dowlati Y. What patients with vitiligo believe about their condition. Int J Dermatol.. 2004;43:811-4.

29. Magin P, Adams J, Heading G, Pond D, Smith W. The psychological sequelae of psoriasis: results of a qualitative study. Psychol Health Med. 2009;14:150-61.

How to cite this article: Manzoni APDS, Townsend RZ, Weber MB, Nagatomi ARS, Pereira RL, Cestari TF. Assessment of the quality of life of pediatric patients with the major chronic childhood skin diseases. An Bras Dermatol. 2012;87(3):361-8. 